\title{
Maatalouslaskenta 2010:n tuloksia
}

Jaana Kyyrä ja Pasi Mattila

Tike - Maa- ja metsätalousministeriön tietopalvelukeskus, PL 310, 00023 Valtioneuvosto, jaana.kyyra@mmmtike.fi

\section{Tiivistelmä}

Vuoden 2010 maatalouslaskennan tulokset osoittavat, että suomalaisen maatalouden rakennemuutos jatkuu. Tilojen määrä vähenee ja viljelijät ovat entistä iäkkäämpiä. Kotieläintilojen viljelijät ovat keskimäärin nuorempia ja he ovat hallinneet tilaa lyhyemmän ajan kuin kasvinviljelytilojen viljelijät. Karjatiloja on aiempaa harvemmassa ja viljatilojen osuus kasvaa.

Suurimmalla osalla kotieläintiloista maatalous on päätoimista, kun taas kasvinviljelytiloilla maataloutta harjoitetaan usein sivutoimisesti. Tehdyn maataloustyön määrä on kotieläintiloilla suurempi kuin kasvinviljelytiloilla, vaikka kasvintuotannossa työskentelevien henkilöiden lukumäärä on suurempi. Kolmannes maa- ja puutarhataloudessa työskentelevistä on naisia.

Suomalainen viljelijä on keskimäärin 51-vuotias ja hän on hallinnut tilaa keskimäärin reilut 20 vuotta. Noin puolella tilojen vastuuhenkilöistä on maatalous- tai puutarha-alan koulutus.

Noin kolmannes Suomen lähes 64000 maatilasta ja puutarhayrityksestä harjoittaa maa- ja puutarhatalouden ohella muuta yritystoimintaa. Monialaisia tiloja on useimmiten kaupungeissa tai niiden läheisyydessä sekä harvaan asutuilla alueilla. Harvinaisempia ne ovat ydinmaaseudulla. Eniten muuta yritystoimintaa on kasvinviljelyyn tai erikoiskasvintuotantoon suuntautuneilta tiloilta. Suhteellisesti yleisintä monialaisuus on hevostiloilla. Monet kotieläintilat ovat keskittyneet vain kotieläintalouteen. Lypsykarja- ja sikatilojen joukossa monialaisten tilojen osuus on pienin.

Lähes 90 prosentilla monialaisista tiloista muussa yritystoiminnassa hyödynnetään maatalous- ja puutarhatuotantoon tarkoitettuja koneita, rakennuksia, aluetta tai tuotteita. Noin 40 prosentilla muuta yritystoiminta harjoittavista tiloista muun yritystoiminnan liikevaihto jää alle 10000 euron vuodessa, joten sillä vain täydennetään maataloutta. Yleisin toimiala on palvelut. Se on liikevaihdoltaan merkittävin muun yritystoiminnan toimiala noin 70 prosentilla monialaisista tiloista.

Maatalouslaskenta 2010:n yhteydessä toteutettiin ensimmäistä kertaa tuotantomenetelmätutkimus, jossa kerättiin tietoa energiankulutuksesta ja -tuotannosta, kastelusta, peltoviljelystä ja kotieläinten hoidosta. Mukana oli noin 14000 maatalous- ja puutarhayritystä eli noin joka viides Suomen tiloista. Näiden tilojen tiedoista on estimoitu kaikkia Suomen tiloja kuvaavat tulokset. Ensimmäiset tuotantomenetelmätutkimuksen tuloksista julkaistiin lokakuussa 2011. Seuraavat julkistukset ovat joulukuussa ja vuoden 2012 tammikuussa.

Tuotantomenetelmätutkimuksen ensimmäisten tulosten mukaan noin puolet Suomen pelloista muokataan ja/tai kylvetään vuoden aikana. Yleisin perusmuokkausmenetelmä on syyskyntö. Keskimäärin viidennes peltoalasta on paljaana talvella. Neljännes pelloista saa lantaa. Lannanlevitykseen käytetyn peltoalan osuus on luonnollisesti karjatiloilla suurempi kuin kasvinviljelytiloilla. Lietelannan levitysalasta lähes kolmanneksella lanta sijoitetaan suoraan maahan ja pintalevitetystä lannasta suurin osa mullataan levityksen jälkeen.

\section{Asiasanat}

Maatalous, talous, rakenne, tilasto 


\section{Johdanto}

Maatalouslaskenta on kaikki maatilat ja puutarhayritykset kattava maatalouden rakennetutkimus, jolla kerätään tietoa maatilojen tuotantovälineistä ja toiminnasta. Maatalouslaskenta toimeenpannaan kymmenen vuoden välein maailmanlaajuisena tilastotutkimuksena FAO:n suositusten mukaisesti. EU:n ja Euroopan talousalueen maissa maatalouslaskentaa ohjaa maatalouden rakennetutkimukseen liittyvä EU-lainsäädäntö. Maatalouslaskentojen välillä suoritetaan 2-3 vuoden välein suppeampia rakennetutkimuksia, joissa tiedot kerätään vain osalta maatiloista. Maatalouslaskennalla saatava tieto on tärkeää aineistoa maatalous- ja elintarvikealan poliittisessa päätöksenteossa ja tutkimuksessa. Suomessa maatalouslaskennat ja rakennetutkimukset toteuttaa Tike - Maa- ja metsätalousministeriön tietopalvelukeskus.

Maatalouslaskenta 2010:n tiedonkeruu tehtiin syksyn 2010 ja talven 2011 aikana kaikille Suomen noin 64000 maatilalle ja puutarhayritykselle. Osa tiedoista saadaan maatalousalan tilastoista ja rekistereistä, mutta paljon asioita kysyttiin suoraan viljelijöiltä. Tiedonkeruun alussa viljelijöillä oli mahdollisuus antaa tiedot sähköisellä lomakkeella Internetin kautta. Maatilat, jotka eivät vastanneet sähköisesti, täyttivät paperilomakkeen, ja tiedot kerättiin puhelinhaastatteluilla. Yli puolet viljelijöistä antoi tiedot sähköisellä lomakkeella. Maatalouslaskennan ennakolliset tulokset on julkaistu Matildamaataloustilastopalvelussa.

\section{Maatalous- ja puutarhayritysten lukumäärä ja tuotantosuunta}

Maatalouslaskennan ennakkotietojen mukaan Suomessa on 63874 maatalous- ja puutarhayritystä. Tilaluku on pienentynyt kymmenessä vuodessa viidenneksen. Noin $90 \%$ maatiloista on perinteisiä perheviljelmiä. Maatalousyhtymiä on $8 \%$. Kaksi prosenttia tiloista omistaa oikeushenkilö eli yhtiö (esim. osakeyhtiö tai osuuskunta), yhdistys, valtio, kunta tai muu yhteisö.

Maatalouden yleisimmät päätuotantosuunnat ovat viljanviljely ja lypsykarjatalous. Vuonna 2000 lypsykarjatiloja oli vielä $28 \%$ tiloista, ja nyt lypsykarjatalouden ilmoitti päätuotantosuunnakseen $18 \%$ maatiloista. Viljatilojen osuus on sen sijaan kasvanut kymmenessä vuodessa 34 prosentista 43 prosenttiin. Enää kolmannes maatiloista toimii kotieläintalouden parissa, kun kymmenen vuotta aiemmin vielä lähes puolet tiloista ilmoitti kotieläintalouden päätuotantosuunnakseen. Osa eläinten pidon lopettaneista tiloista on jatkanut toimintaa viljatiloina, mikä näkyy viljanviljelyn suosion kasvuna. Erikoiskasvituotantoa harjoittavien tilojen osuus on pysynyt likimain ennallaan ja puutarhatuotantoa harjoittavien tilojen osuus pienentynyt. Hevostalouden suhteellinen merkitys on kasvanut selvästi: hevostalouteen suuntautuneiden tilojen osuus on noussut lähes kolmanneksen.

\section{Maatalous- ja puutarhatalouden työvoima}

Maa- ja puutarhataloudessa työskentelevien määrä sekä työaika ovat jatkaneet laskuaan. Maa- ja puutarhatilojen töihin käytettiin vuonna 2010 yhteensä noin 79000 henkilötyövuotta. Yksi henkilötyövuosi on 1800 työtuntia, eli kahdeksan tunnin päivittäinen työ viitenä päivänä viikossa ja yhtenätoista kuukautena vuodessa. Maa- ja puutarhatalouteen kului vuonna 2010 noin 12000 henkilötyövuotta vähemmän kuin vuonna 2000. Luvut eivät ole täysin vertailukelpoisia, koska vuoden 2010 laskelma kattaa kaikki maatilat ja puutarhayritykset, kun taas vuoden 2000 laskuihin eivät sisältyneet pelkkää kasvihuonetuotantoa harjoittaneet puutarhayritykset.

Vuonna 2010 maa- ja puutarhatalous työ̈listi 125300 ihmistä, kun kymmenen vuotta aiemmin maatalouden työvoimaan kuului lähes 178800 henkilöä. Kymmenessä vuodessa henkilöiden määrä on pudonnut $30 \%$, kun taas työmäärä on pienentynyt selvästi vähemmän eli noin $13 \%$. Viljanviljelytiloilla työskentelee lähes $40 \%$ maatalouden työvoimasta. Toiseksi eniten työllistivät lypsykarjatalouteen suuntautuneet tilat. Viljatiloilla työskentelevien työajasta kului maataloustyöhön kuitenkin keskimäärin vain kolmannes kokonaistyöajasta, kun taas karjatiloilla työskentelevien työajasta maataloustyö nielee selvästi pääosan. Lypsykarjatiloilla tehty henkilökohtainen vuosityömäärä onkin yli kaksinkertainen viljatiloihin verrattuna. Tämä näkyy myös työn alueellisessa jakautumisessa: henkilön työmäärä ja maa- ja puutarhatalouden osuus kokonaistyömäärästä ovat keskimäärin suurimmat karjatalousvaltaisilla alueilla. Varsinkin lypsykarjatiloilla tehdään pitkää päivää. Yksi ihminen käyttää tilan töihin keskimäärin 255 päivää vuodessa. Laskennallinen henkilötyövuosi on 225 työpäivää.

Maa- ja puutarhataloudessa työskentelevistä $33 \%$ oli naisia vuonna 2010. Naisia on nyt hieman aiempaa vähemmän, sillä vuonna 2000 naisia oli $36 \%$ tilan työvoimasta. Naisen tapaa todennäköisemmin töissä hevostaloutta harjoittavilla tiloilla. Hevostalouden päätuotantosuunnaksi ilmoittaneilla 
tiloilla naisten osuus työvoimasta on $48 \%$. Myös puutarhatalous on naisten suosiossa: puutarhatalouden päätuotantosuunnakseen ilmoittaneilla tiloilla $46 \%$ työvoimasta on naisia. Vähiten naisia on viljatiloilla. Sen parissa työskentelevistä naisia on vain $27 \%$. Viljanviljely työllistää kuitenkin henkilömäärällisesti eniten sekä naisia että miehiä.

\section{Viljelijöiden ikä}

Suomalainen viljelijä on keskimäärin 51-vuotias. Keski-ikä on noussut kymmenessä vuodessa kolme vuotta, sillä vuonna 2000 se oli 48 vuotta. Keskimäärin nuorimmat viljelijät (47 vuotta) työskentelevät sikatiloilla. Myös lypsykarja-, nautakarja-, siipikarja- ja hevostilojen viljelijöiden keski-ikä on alle 50 vuotta. Alle 35-vuotiaiden osuus on suurin hevostiloilla (14\%), sikatiloilla (12\%) ja lypsykarjatiloilla $(11 \%)$. Muiden tuotantosuuntien viljelijät ovat keskimäärin 50 vuotta tai sen yli. Puutarhatilojen viljelijöissä on paljon iäkkäitä henkilöitä sillä $77 \%$ heistä on yli 45-vuotiaita.

\section{Viljelijöiden koulutus}

Noin puolella maatalous- ja puutarhayritysten vastuuhenkilöistä ei ole maatalous- tai puutarha-alan koulutusta. Hieman yli kolmannes on hankkinut alan peruskoulutuksen eli käynyt esimerkiksi maatalousoppilaitoksen. Kymmenesosalla viljelijöistä on ylempi maatalous- puutarha-alan koulutus, joka tarkoittaa esimerkiksi ammattikorkeakoulu- tai yliopistotutkintoa.

Yleisimmin maatalous- tai puutarha-alan koulutus löytyy karjatilojen vastuuhenkilöiltä. Tästä tekevät poikkeuksen lammas-, vuohi- ja hevostilat, joilla ammatillisen koulutuksen puutetta selittää todennäköisesti se, että usein toiminta on tai oli aluksi harrastusluonteista. Näillä aloilla työskentelevistä monilla on jonkin muun alan koulutus.

Kasvintuotantoon suuntautuneilla tiloilla alan koulutus löytyy todennäköisemmin erikoiskasvintuotantoa ja puutarhatuotantoa harjoittavien tilojen vastuuhenkilöiltä. Näistä koulutuksen on hankkinut noin puolet henkilöistä.

\section{Sukupolvenvaihdos}

Perheviljelmät ja maatalousyhtymät ovat siis olleet nykyisen haltijan tai haltijoiden hallussa keskimäärin reilut 20 vuotta. Hallinta-ajan perusteella luokiteltuna suurimmalla osalla tiloista sukupolvenvaihdos tehtiin 20 - 29 vuotta sitten. Viimeisen viiden vuoden aikana sukupolvenvaihdoksen on tehnyt 10 $\%$ tiloista.

Hallinta-aika ei juurikaan vaihtele alueittain. Aivan eteläisimmissä ja pohjoisimmissa osissa maata hallinta-aika on koko maan keskiarvoa lyhyempi. Hallinta-aika ei näytä olevan riippuvainen viljelijöiden iästä. Varsinais-Suomessa ja Hämeessä nuorimpien viljelijöiden ikäluokkien osuus on koko maan keskiarvoa pienempi, vaikka tila on ollut hallinnassa näillä alueilla keskimääräistä lyhyemmän ajan. Tästä voidaan päätellä se, että eteläosissa viljelijät ovat aloittaneet tilanpidon vanhempina kuin maan keski- ja pohjoisosissa. Myös vanhempien ikäluokkien osuus viljelijöistä on suurempi maan eteläosissa.

Pohjoisen viljelijät ovat keskimääräistä nuorempia, ja vanhempiin ikäluokkiin kuuluu vähemmän viljelijöitä kun muualla maassa. Myös tilojen hallinta-aika on lyhyempi eli tilanpito aloitetaan maan pohjoisosissa nuorempana kuin muualla maassa.

Tuotantosuunta näyttää vaikuttavan tilan hallinta-aikaan alueita enemmän. Kasvihuoneviljelyä päätuotantosuuntanaan harjoittavilla tiloilla viljelijät ovat hallinneet tilaa keskimäärin 21 vuotta. Myös muut kasvintuotantotilat ovat olleet nykyisellä haltijalla yleensä kauemmin kuin kotieläintilat. Kasvintuotantoa päätuotantosuuntanaan harjoittavien tilojen viljelijät ovat keskimäärin vanhempia kuin kotieläintilojen viljelijät.

Lammas-, vuohi- ja hevostaloustilat ovat yleensä olleet hallinnassa muita tiloja lyhyemmän ajan. Viljelijöiden keski-ikä on näillä tiloilla selvästi keskiarvoa alhaisempi ja nuoria viljelijöitä on erityisesti hevostiloilla paljon. Myös sikatilojen viljelijät ovat muita nuorempia ja tilojen hallinta-aika on muita tiloja lyhyempi. 


\section{Tietokoneen ja internetin käyttö}

Maatalous- ja puutarhayrityksistä $83 \%$ käyttää tietokonetta ja liki kaikilla näistä on Internet-yhteys. Yleisin yhteystyyppi on kiinteä laajakaista (66 \% internetiä käyttävistä tiloista) ja toiseksi yleisin mobiili laajakaista (24\%). Mobiilin laajakaistan osuus on suurempi harvaan asutuilla alueilla ja kiinteän laajakaistan osuus pienempi, mikä kuvastaa verkkoyhteyksien tasoeroja eri alueilla.

Tietokoneen käytössä alueiden väliset erot ovat pienet. Internet-yhteyksiä on kuitenkin harvemmin asutuilla alueilla hieman vähemmän kuin tiheämmin asutuilla alueilla. Tuotantosuunnittain tarkasteltuna tietokoneen käyttö ja internet-yhteys ovat yleisimmät sika- ja siipikarjatiloilla.

\section{Monialaiset maatalous- ja puutarhayritykset}

Monialaisia tiloja on Suomessa 19500 eli lähes kolmannes maatalous- ja puutarhayrityksistä harjoittaa maa-, puutarha- ja metsätalouden ohella jonkin muun toimialan yritystoimintaa. Monissa muissa maissa myös metsätalous luetaan muuksi yritystoiminnaksi.

Moninainen yritteliäisyys on perinteisesti ollut yleistä maamme maatiloilla. Muun yritystoiminnan systemaattinen tilastointi aloitettiin vuonna 2000 osana maatalouden rakennetutkimusta. Vuonna 2000 monialaisia maatiloja oli noin $27 \%$ maatiloista ja vuonna 2005 noin $34 \%$, mutta nyt muuta yritystoimintaa harjoittavien osuus on laskenut 31 prosenttiin. Vuonna 2000 muun yritystoiminnan toimialaluokitus erosi jonkin verran nykyisin käytössä olevasta luokituksesta, mikä tulee huomioida vertailuissa.

Tiloilla on eniten muuta yritystoimintaa Varsinais-Suomessa ja Etelä-Pohjanmaalla. Molemmissa toimii lähes parituhatta monialaista tilaa. Vähiten sitä löytyy Kainuusta ja Ahvenanmaalta. Maaseutualueiden eriytyminen näkyy tilastossa. Monialaisuus on tilojen lukumäärään suhteutettuna yleisintä kaupungeissa ja kaupunkien lähiseuduilla sekä harvaanasutuilla alueilla ja selvästi harvinaisempaa ydinmaaseudulla. Monialaisten tilojen osuus kaikista tiloista on suurin Lapissa ja Uudellamaalla, joiden tiloista lähes kaksi viidesosaa on monialaisia. Pienin monialaisten osuus on Etelä-Pohjanmaalla ja Pohjanmaalla, joilla se on neljänneksen luokkaa.

Tilakoon kasvun ja maatalouden rakennemuutoksen yhteydessä on ollut nähtävissä jo pidempään, että monet kotieläintilat erikoistuvat nimenomaan kotieläintalouteen kun taas kasvintuotannossa on enemmän monialaisia tiloja. Tuotantosuunnan tilamäärään suhteutettuna muu yritystoiminta on yleisintä hevostiloilla, erikoiskasvintuotantoa harjoittavilla tiloilla ja luokassa "muu tuotanto". Sika- ja lypsykarjatilojen joukossa taas monialaisten tilojen osuus on pienin. Lukumääräisesti eniten monialaisia tiloja on viljanviljelyyn, muuhun kasvintuotantoon ja lypsykarjatalouteen suuntautuneiden tilojen joukossa. 27400 viljatilasta 8800 on monialaisia. Vähiten monialaisia tiloja toimii siipikarjantuotannossa ja luokassa "muu tuotanto".

Muu yritystoiminta linkittyy yleensä vahvasti tilan maatalouteen ja sen voimavaroihin. Tilojen voimavaroja käytetään siis usealla toimialalla. Tilan maa- tai puutarhatalouteen liittyvää muuta yritystoimintaa harjoittaa 17000 tilaa eli peräti 87 prosentilla muuta yritystoimintaa harjoittavista tiloista muussa yritystoiminnassa hyödynnetään tilan maatalous- tai puutarhatuotannon koneita, rakennuksia, aluetta tai tuotteita.

Muun yritystoiminnan työtehtäviä tekee kaikkiaan 22600 viljelijää, osakasta tai perheenjäsentä. Yhteensä heiltä kuluu muun yritystoiminnan töihin noin 7400 henkilötyövuotta, mikä on $30 \%$ heidän kokonaistyömäärästään. Ulkopuolisia henkilöitä työskentelee tiloilla muun yritystoiminnan parissa kaikkiaan noin 9100 henkeä. Lähes joka kolmas muuhun yritystoimintaan osallistuva on siis tilan ulkopuolinen työntekijä. Työ on luonteeltaan usein kausiluontoista tai osa-aikaista. Palkatut ulkopuoliset henkilöt tekevät muun yritystoiminnan töitä lähes 4800 henkilötyövuotta. Näin ollen palkattu työntekijä työskentelee muussa yritystoiminnassa vuoden aikana keskimäärin hieman yli puolen henkilötyövuoden verran.

Tilojen muu yritystoiminta on monissa tapauksissa melko pienimuotoista niin henkilötyövuosilla kuin liikevaihdollakin mitattuna. On täysin tilakohtaista, kuinka merkittävä osuus liikevaihdosta tulee muun yritystoiminnan kautta ja paljonko työpanosta siihen kuluu. Osalla tiloista maatalouden rooli on merkittävästi isompi tilan liikevaihdon tai työnkäytön osalta, osalla taas maatalouden merkitys on vähäinen ja muun toiminnan vastaavasti suurempi. Noin 40 prosentilla monialaisista tiloista muun yritystoiminnan liikevaihto on alle 10000 euroa vuodessa. Toiminta on tällöin luonteeltaan usein maataloutta täydentävää. Noin 35 prosentilla tiloista muun yritystoiminnan liikevaihto on 10 000-50 000 euroa, 10 prosentilla 50 000-100 000 euroa ja noin 12 prosentilla liikevaihto ylittää 100000 euroa. 
Palvelut on suurin toimiala kaikissa liikevaihtoluokissa, mutta sen osuus pienenee liikevaihdon noustessa. Monialaisista tiloista 77 prosenttia ilmoittaa toimialakseen palvelut alle 10000 euron liikevaihtoluokassa ja 51 prosenttia yli 200000 euron liikevaihtoluokassa. Teollisuuden ja kaupan osuus taas suurenee liikevaihdon lisääntyessä.

Monialaisten tilojen toimialarakenne on viimeisen kymmenen vuoden aikana muuttunut. Palvelualalla toimii nyt hieman suurempi osa tiloista kun taas teollisuudessa toimivien osuus on pudonnut. Muuta alkutuotantoa harjoittavien tilojen määrä on vuodesta 2005 pudonnut noin puoleen, mikä heijastaa näillä toimialoilla tapahtunutta yleisempääkin muutosta. Esimerkiksi poronhoitajien, turkistarhaajien ja kalastajien kokonaismäärä on pudonnut merkittävästi viimeisen vuosikymmenen aikana.

Monilla tiloilla harjoitetaan useita toimialoja samanaikaisesti, esimerkiksi sekä urakointia että matkailua. Noin 70 prosenttia monialaisista tiloista on ilmoittanut merkittävimmäksi muun yritystoiminnan toimialaksi palvelut. Noin 14 prosenttia tiloista toimii teollisuudessa. Viisi prosenttia tiloista toimii muussa alkutuotannossa kuin maataloudessa ja neljä prosenttia kaupan alalla.

Palvelut on päätoimialana noin 13800 tilalla. Suosituin palveluala on urakointi, jota tekee 8900 tilaa. Urakoinnilla tarkoitetaan maatalouskoneurakointia, metsäkoneurakointia, bioenergiaurakointia, maanrakennuspalveluita sekä teiden aurausta ja kunnossapitoa. Maatalouskoneilla voidaan tehdä monenlaisia töitä niin maataloudessa kuin muillakin aloilla ja usein koneita tarvitaan tilan omissa töissä vain osan ajasta. Urakoinnilla koneita voidaan käyttää myös tilan ulkopuolella, mikä antaa sekä koneille että tilan työvoimalle lisää taloudellisesti tuottavaa työaikaa. Matkailupalveluja tarjoaa noin 1400 monialaista tilaa. Muita merkittäviä palvelutoimialoja ovat ratsastus ja muut hevosalan palvelut, kuljetuspalvelut sekä liike-elämää palveleva toiminta. Hoito- ja hoiva-alalla toimii kaikkiaan noin 170 monialaista tilaa, joista noin 120:1lä se on muun yritystoiminnan päätoimiala.

Teollisuuden parissa toimii kaikkiaan joka neljäs monialainen tila eli kaikkiaan noin 4850 tilaa. Näistä noin 2750 ilmoittaa teollisuuden päätoimialakseen. Suurimpia toimialoja ovat energian tuotanto, elintarvikkeiden jatkojalostus ja puutavaran jatkojalostus. Teollisuudella eli valmistuksella tarkoitetaan materiaalien, aineiden ja komponenttien mekaanista, kemiallista tai biologista muuntamista uusiksi tuotteiksi (Toimialaluokitus 2008). Maatilojen teollisen toiminnan tärkeimmät raaka-aineet ovat tiloilta saatavat puu ja maataloustuotteet.

Muuta alkutuotantoa kuin maa-, puutarha- tai metsätaloutta harjoittaa noin 1200 tilaa. Muun yritystoiminnan päätoimialana se on noin tuhannella tilalla. Alkutuotantoon suuntautuneiden tilojen määrä on hieman pudonnut vuodesta 2005. Suurimmat toimialat ovat poronhoito ja turkistarhaus. Muita ovat esimerkiksi kalastus ja kalojen tai rapujen kasvatus sekä riistan tarhaus.

Rakennusalan töitä teki kaikkiaan noin 700 monialaista tilaa, joista noin 400 ilmoitti sen päätoimialakseen. Rakennustoimintaa harjoittavien tilojen määrän puolittuminen johtuu osittain 2000luvun lopun taantumasta, joka vähensi rakentamista yleisestikin. Kaupan alalla toimii noin 1550 tilaa, ja päätoimialana se on noin 850 tilalla.

\section{Peltojen muokkaus}

Noin puolelle Suomen peltoalasta (käytössä oleva maatalousmaa) tehtiin muokkaus, kylvö tai molemmat heinäkuun 2009 alun ja kesäkuun 2010 lopun välisenä aikana. Kasvintuotantotiloilla yksivuotisten kasvien viljely on yleistä, ja niillä muokatun tai kylvetyn alan osuus on noin kaksi kolmannesta.

Lypsykarja- ja nautakarjatiloilla on paljon monivuotista nurmea. Näillä tiloilla vain noin kolmannes peltoalasta muokattiin tai kylvettiin vuoden aikana. Kaikkein suurin muokkaus- tai kylvöala on sika- ja siipikarjatiloilla, jotka viljelevät viljaa karjansa rehuksi. Pienin muokatun tai kylvetyn maan osuus on lammas- ja vuohitiloilla sekä hevostiloilla, joilla suuri osa maatalousmaasta on monivuotisena tai pysyvänä rehu- tai laidunnurmena.

Yleisin perusmuokkausmenetelmä on edelleen syyskyntö, jota käytetään lähes puolella muokatusta tai kylvetystä peltoalasta. Kevennetysti muokataan noin neljännes pelloista ja kevätkynnön osuus on 14 prosenttia. Suorakylvön osuus on 13 prosenttia muokatusta tai kylvetystä peltoalasta. Tuotantosuunnista kynnön osuus on suurin lypsykarja-, muu nautakarja-, lammas- ja vuohi- sekä hevostiloilla, joilla kynnettiin noin kolme neljäsosaa muokatusta tai kylvetystä alasta. Näillä tiloilla on paljon nurmea ja suuri osa lannasta käsitellään kiinteänä. Kyntöä tarvitaan nurmien lopettamiseen ja kiinteän lannan tehokkaaseen multaamiseen. Tämän vuoksi vaihtoehtoisia muokkausmenetelmiä ei voida käyttää yhtä laajasti kuin muissa tuotantosuunnissa. 


\section{Peltojen peitteisyys talvella}

Keskimäärin 20 prosenttia peltoalasta on paljaana talvella. Paljon yksivuotisia kasveja viljelevillä sika-, siipikarja-, erikoiskasvi- ja puutarhatiloilla paljaan maan osuus talviaikaan on noin 30 prosenttia. Kasvipeitteisyys talvella on suurinta nurmivaltaisilla lammas-, hevos- ja nautakarjatiloilla, joilla paljaan maan osuus jää 5-14 prosenttiin.

Talvella paljaana olevan maatalousmaan osuus on suurin eteläisellä Pohjanmaalla ja Satakunnassa. Eteläisen Pohjanmaan alueilla viljellään paljon yksivuotisia viljelykasveja (esimerkiksi kevätviljoja ja perunaa), mutta Etelä-Suomeen verrattuna syysviljojen viljely on vähäisempää ja kevennettyyn muokkaukseen sopivien maalajien osuus on pienempi. Satakunnassa yksivuotisten avomaan puutarhakasvien runsas viljely lisää osaltaan talvikaudella paljaana olevaa peltoalaa.

\section{Saman kasvin jatkuva viljely}

Vähintään kolme peräkkäistä vuotta samalla viljelykasvilla olleen peltoalan osuus on suurin runsaasti viljaa rehuksi viljelevillä sikatiloilla. Niillä viljely keskittyy usein vain muutamaan kasvilajiin, jolloin monokulttuuri eli yhden kasvilajin viljely on yleistä. Jos viljelykasvi on sama useampana vuotena peräkkäin, monet tuhoeläimet, kasvitaudit ja rikkakasvit runsastuvat pienentäen viljelykasvin satoa. Muilla kotieläintiloilla viljellään yleensä sekä viljaa että nurmea, mikä monipuolistaa kasvilajivalikoimaa.

Alueellisesti tarkasteltuna samalla kasvilla vähintään kolme vuotta peräkkäin olleen alan osuus on suurin Pohjanmaalla ja pienin Uudellamaalla. Pohjanmaalla jatkuvaa saman lajin viljelyä lisää monien tilojen erikoistuminen kevätviljojen tai perunan viljelyyn. Uudellamaalla on myös paljon viljatiloja, mutta eteläinen sijainti mahdollistaa laajemman kasvilajivalikoiman. Esimerkiksi VarsinaisSuomeen verrattuna Uudellamaalla on vähemmän sika- ja siipikarjatiloja ja näin ollen pienempi tarve jatkuvaan rehuviljan viljelyyn.

Nurmi on usein samalla lohkolla monta vuotta peräkkäin, mutta monivuotisella nurmella monokulttuurin haitat eivät ole yhtä ilmeisiä kuin yksivuotisilla kasveilla. Nurmivuosina muokkaus- ja kylvötyöt eivät tiivistä maata ja ympärivuotinen kasvipeite estää ravinteiden huuhtoutumista. Siksi jatkuva monivuotisen nurmen viljely ei ole samalla tavalla haitallista kuin saman yksivuotisen kasvilajin viljely useana peräkkäisenä vuotena. Nurmenkin viljelyyn tulee tavallisesti tauko, kun se uudistetaan muutaman vuoden välein.

\section{Karjanlannan levitys}

Lannanlevitykseen käytetyn peltoalan osuus on luonnollisesti suurin karjatiloilla. Nauta- ja sikatiloilla noin 40-60 prosenttia peltoalasta sai lantaa heinäkuun 2009 alun ja kesäkuun 2010 lopun välisenä aikana. Näissä tuotantosuunnissa lietelannan levitysala on suurempi kuin kiinteän lannan, joten suurin osa lannasta käsitellään nykyään lietelantana. Muissa karjatalouden tuotantosuunnissa lanta käsitellään ja levitetään edelleen pääosin kiinteänä. Lammas- ja vuohitaloudessa sekä hevostaloudessa lannan levitystä vähentää runsas laiduntaminen, jolloin suuri osa lannasta jää laitumelle eikä vaadi erillistä levitystä. Kasvintuotantotiloilla lannan käyttö on vähäistä (noin 5-10 prosenttia peltoalasta), joten lantaa ei juurikaan viedä karjatiloilta kasvinviljelytilojen pelloille.

Karjatalousvaltaisessa Pohjois-Savossa lantaa saaneen peltoalan osuus on alueista suurin ja se on korkea myös muilla karjavaltaisilla alueilla kuten Pohjanmaalla, Kainuussa, Lapissa ja PohjoisKarjalassa. Pohjanmaalla turkiseläinten lanta lisää osaltaan lannanlevitystä.

Lietelannan levitysalasta jo lähes kolmanneksella lanta sijoitetaan suoraan maahan ja pintalevitetystäkin lannasta suurin osa mullataan levityksen jälkeen, mikä edistää lannan ravinteiden hyväksikäyttöä ja vähentää ravinnepäästöjä ympäristöön. Kiinteää lantaa saaneesta alasta vain kymmenesosalla lanta jää multaamatta.

Virtsaa ja lantavettä levitetään muita lantalajeja useammin kasvustoon, minkä vuoksi pintalevitys ilman multausta on selvästi yleisin levitystekniikka tällä lantalajilla. Kevät- ja syysmuokkaus yleensä multaavat luontevasti keväällä ja syksyllä levitetyn lannan. Kasvukauden aikana viljelykasvien kasvustoon levitetty lanta jää kuitenkin pellon pinnalle, ellei sitä sijoiteta suoraan maahan. 


\section{Linkkejä maataloustilastoihin}

Tike - Maa- ja metsätalousministeriön tietopalvelukeskus http://www.mmmtike.fi/fi/

Eurostat, Agricultural statistics http://epp.eurostat.ec.europa.eu/portal/page/portal/agriculture/introduction

FAO World Census of Agriculture http://www.fao.org/economic/ess/world-census-of-agriculture/en/

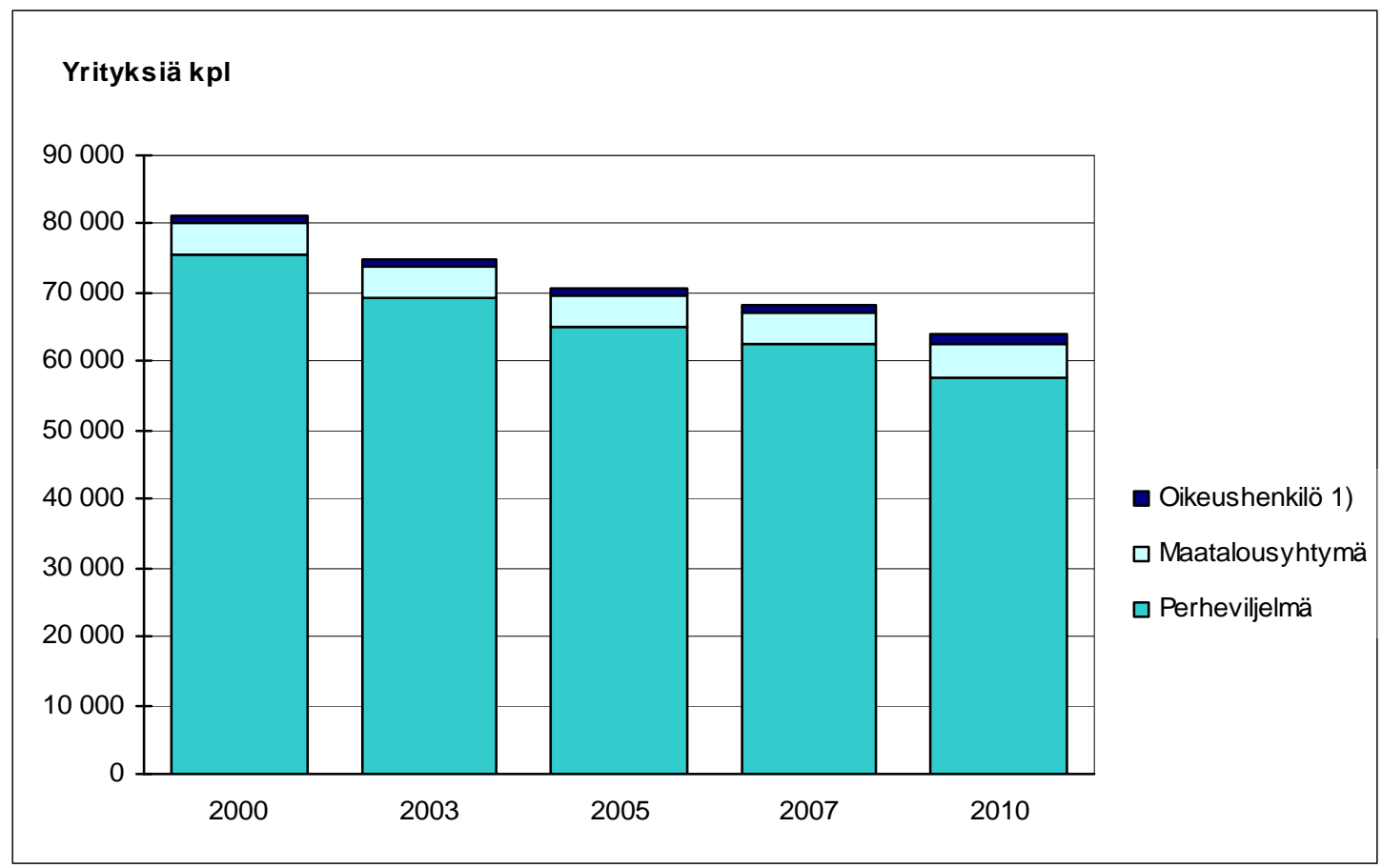

1) Omistajana on yhtiö (esim. osakeyhtiö tai osuuskunta), yhdistys, valtio, kunta tai muu yhteisö.

Kuva 1. Maatalous- ja puutarhayritysten lukumäärä Suomessa 2000-2010. Lähde: Tike.

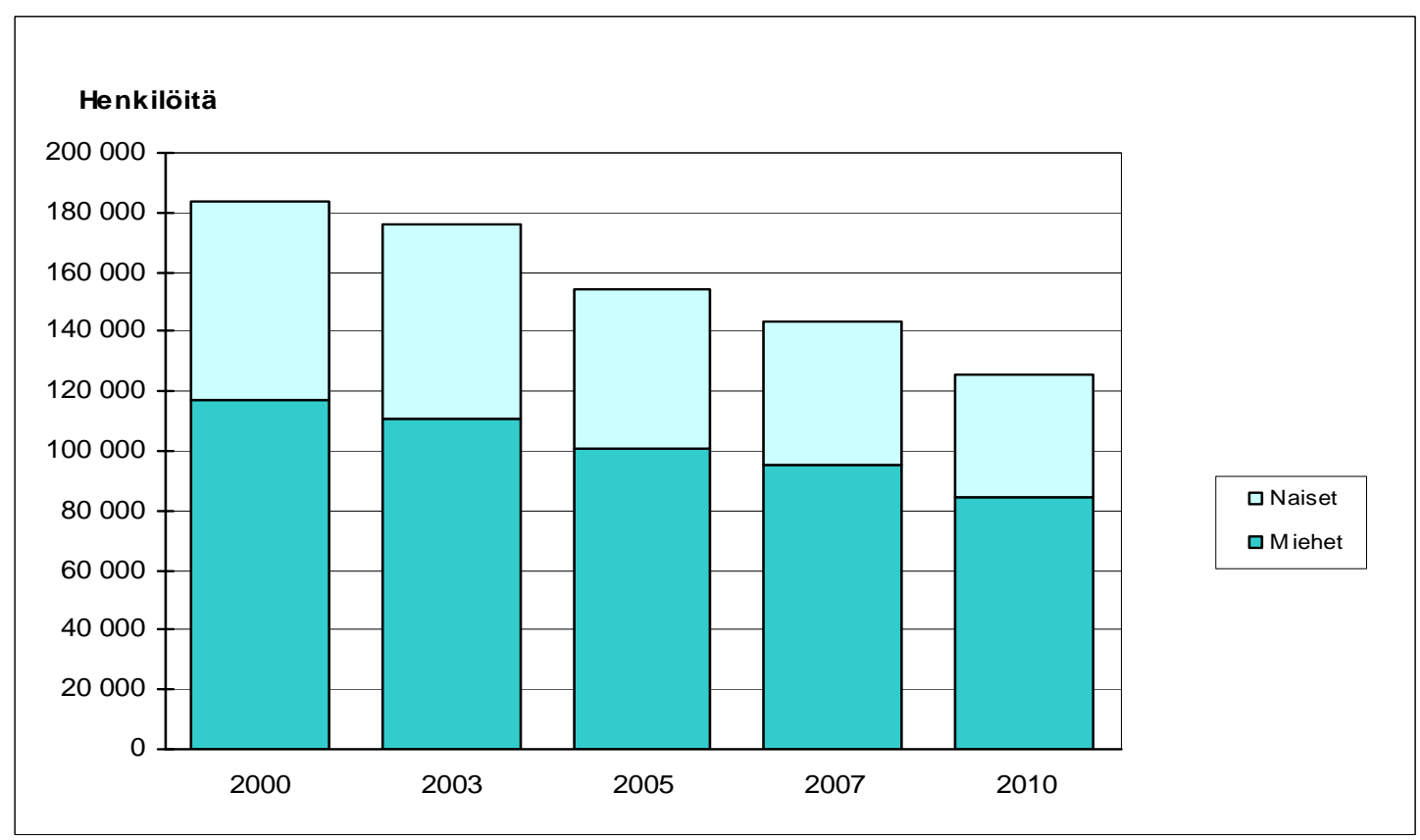

Kuva 2. Maatalous- ja puutarhayritysten työvoima 2000-2010. Maa- ja puutarhatalouden työtä tehneet viljelijät, heidän perheenjäsenensä ja vakituisesti palkattu työvoima. Lähde: Tike. 